\title{
Influence of EI Niño on the Upper-Ocean Circulation in the Tropical Atlantic Ocean
}

\author{
KATJA LOHMANN \\ Max-Planck-Institut für Meteorologie, Hamburg, Germany \\ MoJiB LATIF \\ Leibniz-Institut für Meereswissenschaften, Kiel, Germany
}

(Manuscript received 12 April 2005, in final form 5 February 2007)

\begin{abstract}
This study investigates the influence of El Niño on the upper-ocean circulation in the tropical Atlantic Ocean (via changes in the Atlantic trade winds) by analyzing observed sea surface temperature (SST) together with an ocean general circulation model integration forced by the NCEP-NCAR reanalysis. During periods with anomalously warm (cold) eastern equatorial Pacific SST, the southern Atlantic tropical cell is strengthened (weakened). The difference of the cell strength between El Niño and La Niña years is about $20 \%$ of the mean cell strength. However, the variability of the cell is not dominated by the remote forcing from the eastern equatorial Pacific but seems to be caused by intrinsic tropical Atlantic variability. A strengthening (weakening) for periods with anomalously warm (cold) eastern equatorial Pacific SST is also found for the zonal surface and subsurface currents. TOPEX/Poseidon altimetry data are used to validate the results based on the OGCM integration.
\end{abstract}

\section{Introduction}

An influence of the El Niño-Southern Oscillation (ENSO) phenomenon on the tropical Atlantic Ocean, especially its sea surface temperature (SST), has been shown in previous observational and modeling studies (e.g., Curtis and Hastenrath 1995; Latif and Barnett 1995; Enfield and Mayer 1997; Chiang et al. 2000; Latif and Grötzner 2000; Saravanan and Chang 2000). Some studies suggest that variations of the tropical Pacific SST affect the trade winds over the Atlantic Ocean (e.g., Enfield and Mayer 1997; Wu et al. 2002). A change in the trade winds, however, will likely change the wind-driven shallow subtropical-tropical meridional overturning circulation. The so-called subtropical cells (STCs) are shallow meridional overturning cells with an upwelling at the equator, a poleward Ekman transport at the surface, subduction in the subtropics and an equatorward return flow within the thermocline (McCreary and Lu 1994; Liu 1994). The equatorial upwelling is partly balanced by downwelling within the

\footnotetext{
Corresponding author address: Katja Lohmann, Nansen Environmental and Remote Sensing Center, Thormohlensgate 47, 5006 Bergen, Norway.

E-mail: katja.lohmann@nersc.no
}

Tropics (at about $5^{\circ} \mathrm{S}$ and $5^{\circ} \mathrm{N}$ ), forming relatively narrow recirculation cells that are referred to as tropical cells (TCs; Lu et al. 1998). In the Atlantic, an STC mainly exists in the Southern Hemisphere. The interaction of the northward-flowing upper branch of the Atlantic meridional overturning circulation (MOC) with the shallow upwelling along the equator results in a much reduced supply of North Atlantic water to the equatorial thermocline (Fratantoni et al. 2000). Apart from the (zonally integrated) shallow meridional overturning circulation, the ENSO-induced wind changes over the tropical Atlantic will likely also affect the wind-driven surface and subsurface zonal currents, like the South Equatorial Current (SEC) or the Equatorial Undercurrent (EUC). In this study we use observed SST together with an ocean general circulation model integration forced by the National Centers for Environmental Prediction-National Center for Atmospheric Research (NCEP-NCAR) reanalysis to investigate if an influence of El Niño onto the upper-ocean circulation in the tropical Atlantic can be found.

\section{Data}

In this chapter we shortly describe the observations and model integration on which our study is based. The

DOI: $10.1175 / J C L I 4292.1$ 


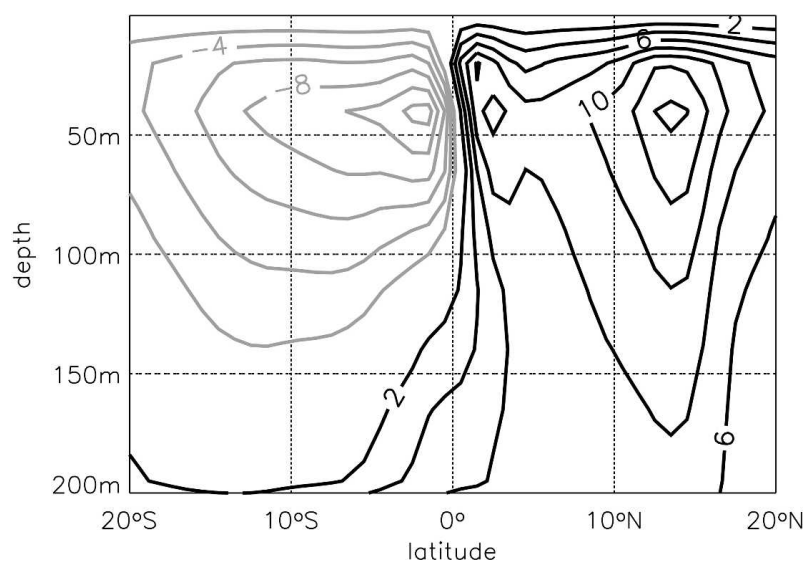

FIG. 1. Climatologically averaged (1948-2001) Atlantic shallow meridional overturning streamfunction taken from the OGCM integration forced by the NCEP reanalysis. Black (gray) lines represent (anti)clockwise flow. The contour interval is $2 \mathrm{~Sv}$.

observed SST is taken from the Hadley Centre Global Sea Ice and Sea Surface Temperature (HadISST1) dataset encompassing the years 1870 to 1998 (Rayner et al. 2003). The tropical Atlantic upper-ocean circulation variability is determined from a 54-yr-long integration of the ocean general circulation Max Planck Institute Ocean Model (MPI-OM) forced by the NCEP-NCAR reanalysis (Kalnay et al. 1996) for the years 1948 to 2001. The forcing includes wind stress, freshwater flux, and heat flux. The latter is not taken from the reanalysis but calculated according to bulk formulas (see Marsland et al. 2003). The MPI-OM model, described by Marsland et al. (2003), is a version of the Hamburg Ocean Primitive Equation model (HOPE) using a Cgrid and orthogonal curvilinear coordinates. For the integration used in this study, the poles are located at $30^{\circ} \mathrm{W}$ and $80^{\circ}$ latitude, respectively. The zonal resolution amounts to about $2.5^{\circ}$ in the tropical and subtropical Atlantic Ocean. Meridionally, an equatorial refinement is used, with a resolution of $0.5^{\circ}$ between about $10^{\circ} \mathrm{S}$ and $10^{\circ} \mathrm{N}$. Poleward of $10^{\circ}$ latitude, the meridional resolution is gradually increased, amounting to about $2^{\circ}$ at $30^{\circ}$ latitude in the Atlantic Ocean. A plot of the horizontal grid used in this study can be found in Marsland et al. (2003, their Fig. 2). Vertically, 23 levels were used, of which nine are in the upper $250 \mathrm{~m}$. Initial conditions were obtained from an extended-range integration with climatological forcing. The Atlantic shallow meridional overturning circulation simulated by the model is shown in Fig. 1. We performed a similar integration with a higher-resolution version of the model, with a horizontal resolution of $1.5^{\circ} \times 1.5^{\circ}$ and 40 vertical levels. The results remained virtually unchanged and are therefore not shown here. All data used in this study are monthly data with the climatological annual cycle (averaged over the period 1948 to 1998) removed.

\section{Influence of El Niño onto the tropical Atlantic}

Figure 2a shows the composite difference based on warm minus cold observed Niño-3 $\left(5^{\circ} \mathrm{S}-5^{\circ} \mathrm{N}, 150^{\circ}-\right.$ $\left.90^{\circ} \mathrm{W}\right)$ SST for the Atlantic shallow meridional overturning streamfunction in the upper-tropical ocean taken from the ocean general circulation model (OGCM) integration forced by the NCEP reanalysis. The threshold value for the composites is one standard deviation of the Niño-3 SST index (1948 to 1998). The index time series consists of monthly values (with all months being considered) with a 1-yr running mean applied and it has been detrended prior to the composite analysis. The periods in which the Niño-3 SST index exceeds plus one standard deviation are "June 1951January 1952, June 1957-April 1958, August 1963October 1963, June 1965-February 1966, June 1969October 1969, May 1972-February 1973, September 1976-November 1976, May 1982-July 1983, January 1987-November 1987, November 1991-March 1992, and May 1997-May 1998"; the periods in which the Niño-3 SST index exceeds minus 1 standard deviation are "January 1950-May 1950, July 1954-March 1956, August 1964-September 1964, November 1967January 1968, July 1970-September 1971, July 1973January 1976, July 1984-January 1986, May 1988-June 1989, and September 1995-April 1996." The details of the composite difference are the same for all other variables shown in Fig. 2. In Fig. 2a, the Niño-3 SST is leading the Atlantic shallow meridional overturning by 4 months. This lag is taken from the cross-correlation function between the Niño-3 SST and the strength of the Southern Hemispheric Atlantic TC (hereafter called the southern TC index). We define the latter as $-\mathrm{psi}_{\text {min }}\left(5^{\circ} \mathrm{S}\right.$ to equator, surface to $\left.150 \mathrm{~m}\right)$, where psi is the Atlantic shallow meridional overturning streamfunction (Fig. 1; note that for the Southern Hemisphere the mean shallow meridional overturning is negative). The maximum correlation between the Niño-3 SST index and the southern TC index amounts to 0.35 , which is statistically significant at the $95 \%$ level (according to a $t$ test) but relatively weak, indicating that the variability of the Southern Hemispheric TC is not dominated by remote forcing from the tropical Pacific. For periods with an anomalously warm (cold) eastern equatorial Pacific the South Atlantic TC is strengthened (weakened). Note that for the Southern Hemisphere cells negative (positive) anomalies correspond to a strength- 
a)

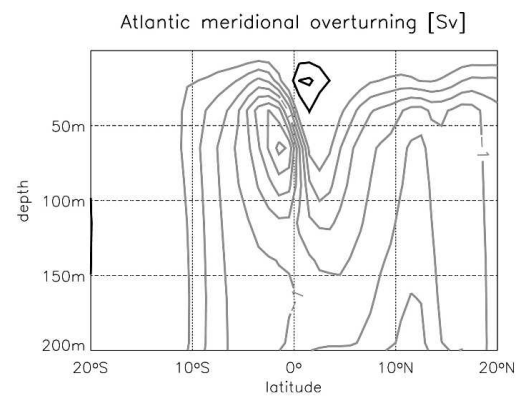

c)

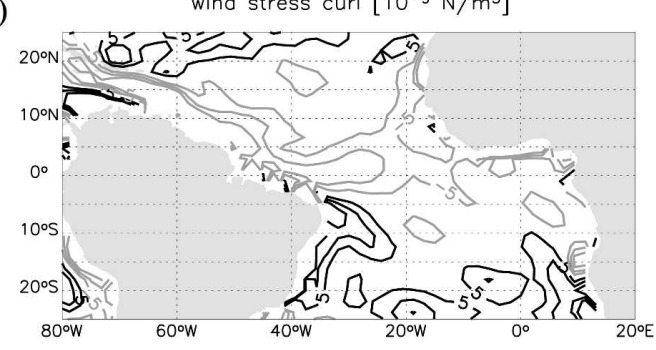

e)

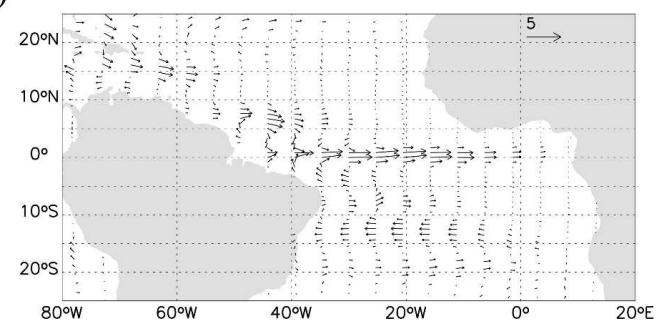

b)

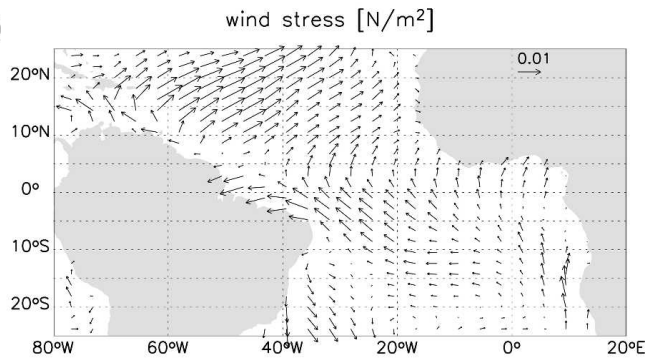

d)

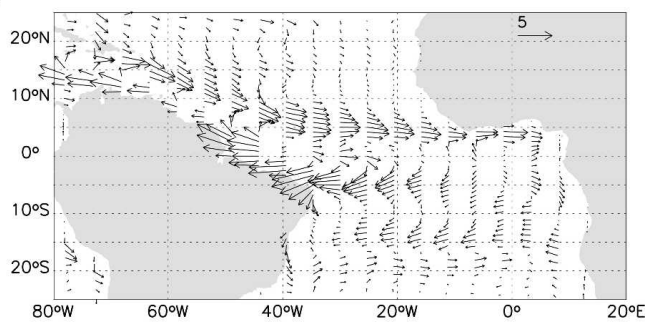

f)

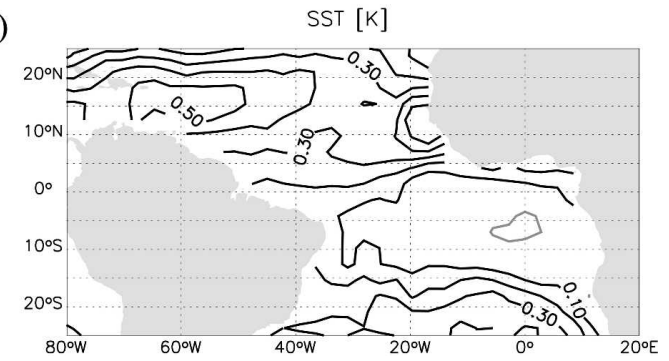

FIG. 2. Composite difference based on warm minus cold observed Niño-3 SST for (a) the Atlantic shallow meridional overturning streamfunction (in Sv), (b) the wind stress (in $\mathrm{N} \mathrm{m}^{-2}$ ), (c) the wind stress curl (in $10^{-9} \mathrm{~N}$ $\mathrm{m}^{-3}$ ), (d) the horizontal velocity at the surface (in $\mathrm{cm} \mathrm{s}^{-1}$ ), (e) the horizontal velocity at 100-m depth (in $\mathrm{cm} \mathrm{s}^{-1}$ ), and (f) the observed SST (in K). The shallow meridional overturning as well as the horizontal velocities are taken from the OGCM integration forced by the NCEP reanalysis; the wind stress (curl) is taken from the NCEP reanalysis. The Niño-3 SST is leading by [(a), (b), (c), (f)] 4, (d) 3, and (e) 6 months. All time series are monthly values with a 1-yr running mean applied and have been detrended prior to the composite analysis. The threshold value for the composite is 1 std dev of the Niño-3 SST index. Contour levels are (a) $\pm(0.25,0.5,0.75,1,1.25,1.5$, 1.75 , and 2.0) Sv; (c) $\pm\left(5,10\right.$, and 15) $\times 10^{-9} \mathrm{~N} \mathrm{~m}^{-3}$; and (f) $\pm(0.1,0.2,0.3,0.4$, and 0.5$) \mathrm{K}$. Black (gray) lines represent positive (negative) values. In (b), (d), and (e), only every second vector in longitude direction is shown; in (d) and (e) in the equatorial region, also only every second vector in latitude direction.

ening (weakening). The anomalous circulation only weakly changes the South Atlantic STC. This is true even if we examine longer lag times of the circulation (relative to Niño-3) and also if the composite analysis is repeated with a model integration with a higher horizontal and vertical resolution. We conclude that the Southern Hemispheric STC adjusts slower than the relatively narrow Southern Hemispheric TC and does not respond on interannual time scales, which is consistent with previous studies (e.g., Liu 1998). The difference in the strength of the South Atlantic TC between El Niño and La Niña years is about $2 \mathrm{~Sv}(1 \mathrm{~Sv} \equiv$ $10^{6} \mathrm{~m}^{3} \mathrm{~s}^{-1}$ ) or $15 \%-20 \%$ of the mean strength. The latter is about $12 \mathrm{~Sv}$ in our OGCM integration (Fig. 1), which is within the range of the observational estimates (Zhang et al. 2003).

Since mainly the Southern Hemispheric TC is affected by El Niño, the question arises if any influence of El Niño onto the cross-equatorial ocean heat transport in the Atlantic Ocean can be found. The composite difference based on warm minus cold observed Niño-3 SST for the Atlantic meridional heat transport (not shown) suggests indeed a weakening (strengthening) of the northward heat transport at the equator during periods with anomalously warm (cold) Niño-3 SST. The change in the cross-equatorial Atlantic heat transport 
a)

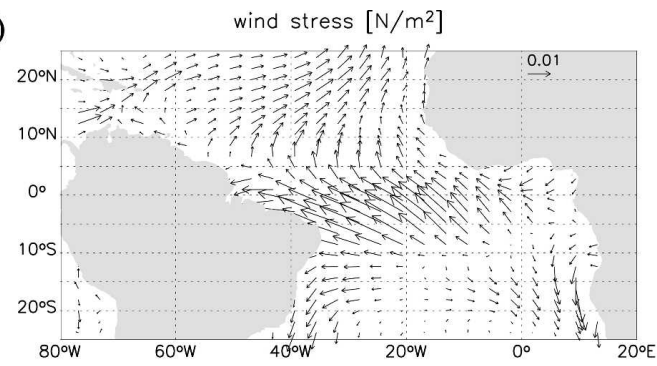

c)

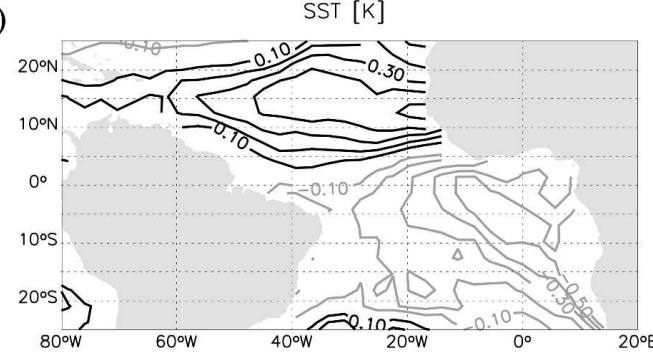

b)

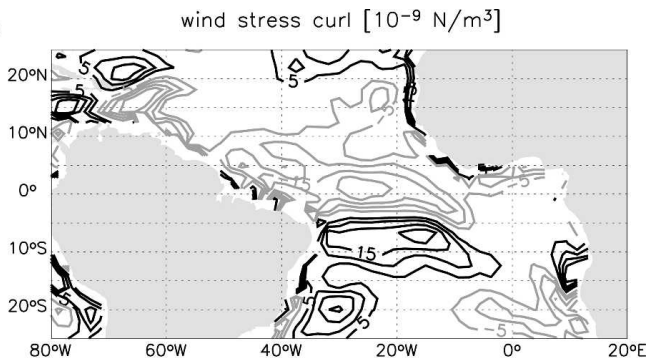

d)

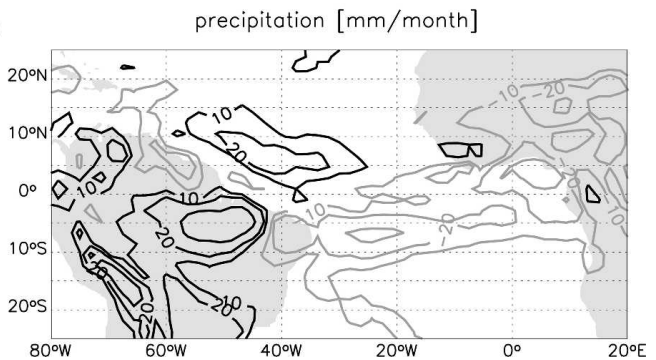

FIG. 3. Composite difference based on strong minus weak Atlantic southern TC index (taken from the OGCM integration forced by the NCEP reanalysis) for (a) the wind stress (in $\mathrm{N} \mathrm{m}^{-2}$ ), (b) the wind stress curl (in $10^{-9} \mathrm{~N}$ $\mathrm{m}^{-3}$ ), (c) the observed SST (in K), and (d) the precipitation (in $\mathrm{mm} \mathrm{month}^{-1}$ ). The wind stress (curl) as well as the precipitation is taken from the NCEP reanalysis. All time series are monthly values with a 1-yr running mean applied and have been detrended prior to the composite analysis. The threshold value for the composite is 1 std $\mathrm{dev}$ of the southern TC index. Contour levels are (b) $\pm(5,10,15$, and 20$) \times 10^{-9} \mathrm{~N} \mathrm{~m}^{-3}$, (c) $\pm(0.1,0.2,0.3,0.4$, and 0.5$) \mathrm{K}$, and (d) $\pm(10,20$, and 40$) \mathrm{mm} \mathrm{month}^{-1}$. Black (gray) lines represent positive (negative) values. In (a) only every second vector in longitude direction is shown.

between El Niño and La Niña years in our OGCM simulation amounts to $0.08 \mathrm{PW}\left(1 \mathrm{PW}=10^{15} \mathrm{~W}\right)$ or about $50 \%$ of the mean cross-equatorial heat transport (0.15 PW).

The change in the South Atlantic TC goes along with a change in the trade winds over the Atlantic Ocean. In Fig. 2b the composite difference based on warm minus cold observed Niño-3 SST for the wind stress from the NCEP reanalysis is shown. As in Fig. 2a, the Niño-3 SST is leading by 4 months, but the wind stress pattern remains unchanged if the lag is increased or decreased by a few months. This is consistent with Keenlyside and Latif (2007), who found similar correlation coefficients between the Niño-3 SST and the wind in the tropical Atlantic 5 months before to 5 months after the Niño-3 SST. During periods with anomalously warm (cold) Niño-3 SST, the southeasterly trade winds strengthen (weaken), while the northeasterly trades weaken (strengthen). This pattern is consistent with previous studies (e.g., Curtis and Hastenrath 1995; Enfield and Mayer 1997; Wu et al. 2002). The changes in the southeasterly trades will lead to an enhanced (reduced) Ekman transport divergence in the ocean, which in turn will increase (decrease) the equatorial upwelling as can be seen in Fig. 2a as well as in the Niño-3 SST compos- ite difference for the upper-ocean vertical velocity (not shown). The Niño-3 SST composite difference for the wind stress curl (Fig. 2c) shows anomalies favoring Ekman downwelling (upwelling) at about $10^{\circ} \mathrm{S}$ in the western part of the basin $\left(w_{e} \sim \operatorname{curl} \tau / f\right)$ during an anomalously warm (cold) Niño-3 SST. Also the effect of the wind stress curl anomalies can be seen in Fig. 2a, as well as in the Niño-3 SST composite difference for the upper-ocean vertical velocity (not shown), which suggests the strongest downwelling (upwelling) between about $5^{\circ}$ and $10^{\circ} \mathrm{S}$ in the western part of the basin.

To investigate if the seasonal locking (e.g., Curtis and Hastenrath 1995) affects our composites, we also calculated Niño-3 composites chosen by fixed months [e.g., September-November (SON) or DecemberFebruary (DJF) for the Niño-3 SST index]. The results remain nearly similar and are therefore not shown here.

In Figs. $3 \mathrm{a}$ and $3 \mathrm{~b}$ the wind stress (curl) pattern over the tropical Atlantic based on a strong minus weak southern TC index is shown. The threshold value for the composites is one standard deviation of the southern TC index. The index consists of monthly values with a 1-yr running mean applied and it has been detrended prior to the composite analysis. The periods in which the southern TC index exceeds one standard de- 
viation are "October 1950-June 1951, September 1952January 1953, October 1957-October 1958, September 1969-May 1970, December 1971-August 1972, October 1977-June 1978, March 1979-May 1979, November 1979-October 1981, December 1982-September 1983, February 1987, July 1992-August 1992, and October 1996-February 1997"; the periods in which the southern TC index exceeds minus 1 standard deviation are "March 1949-May 1949, November 1956-January 1957, May 1961, June 1962-August 1962, November 1962December 1964, October 1966-July 1967, June 1968November 1968, January 1974-August 1974, February 1986-April 1986, November 1988-October 1989, and October 1993-January 1995." Note that the time periods are quite different from the ones defining the Niño-3 SST composites. Again, this indicates that the variability of the South Atlantic TC is not dominated by remote forcing from the tropical Pacific but determined mainly by intrinsic tropical Atlantic variability (or remote forcing from regions other than the tropical $\mathrm{Pa}$ cific). Quite strong El Niño/La Niña events, such as the El Niño 1982/83 or the La Niña 1988/89, are, however, followed by changes in the South Atlantic TC, which exceed 1 standard deviation of the southern TC index. Overall, the wind stress (curl) pattern in Fig. 3 resembles the pattern that goes along with changes in the Niño-3 SST (Figs. 2b,c), indicating that the ENSOinduced wind changes can indeed cause variability in the South Atlantic TC. However, the amplitude of the ENSO-induced changes of the southeasterly trades, as well as of the wind stress curl at $5^{\circ}$ to $10^{\circ} \mathrm{S}$, is only about half of what is found for the southern TC index. Note that in Fig. 3 the patterns for lag zero are shown, but a similar picture is obtained if the wind is leading the cell index by a few months.

In Fig. $3 c$ the pattern for the observed SST (taken from the HadISST1 dataset) based on a strong minus weak southern TC index is shown. The SST from the HadISST1 dataset is chosen, because the simulated SST is not an independent variable in our model setup. During periods with a strong (weak) Southern Hemispheric TC, an anomalously cold (warm) SST in the equatorial as well as the tropical/subtropical South Atlantic and an anomalously warm (cold) SST in the tropical/subtropical North Atlantic are found. The SST anomaly pattern resembles the Atlantic SST dipole mode (e.g., Moura and Shukla 1981). The enhanced (reduced) equatorial upwelling, which goes along with a strong (weak) Southern Hemispheric TC (not shown) will contribute to the cold (warm) equatorial SST anomalies, especially in the eastern part of the basin, where the vertical temperature gradient in the upper ocean is large $\left(10^{\circ} \mathrm{C}\right.$ between the surface and $100-\mathrm{m}$ depth ac- cording to the Levitus data). In the eastern part, the shoaling (deepening) of the thermocline during periods with a strong (weak) Southern Hemispheric TC (not shown) will also contribute to the equatorial SST anomalies. Apart from the vertical advection, the horizontal temperature advection will also influence the SST. During periods with a strong (weak) Southern Hemispheric TC, the South Equatorial Current is strengthened (weakened), which leads to a negative (positive) temperature advection in the western part of the tropical South Atlantic (not shown). The heat flux (not shown) is damping the SST anomalies in the equatorial and the tropical South Atlantic but contributes to the SST anomalies in the tropical North Atlantic. The composite difference for the precipitation (Fig. 3d) shows reduced (increased) precipitation over the Sahel and increased (reduced) precipitation over the Nordeste during periods with a strong (weak) Southern Hemispheric TC. The precipitation changes are consistent with the SST anomalies (e.g., Hastenrath and Lamb 1977; Moura and Shukla 1981).

Apart from the Southern Hemispheric TC, the ENSO-induced changes in the Atlantic trade winds will also affect the wind-driven surface and subsurface zonal currents. Figures $2 \mathrm{~d}$ and 2e show the composite differences based on warm minus cold observed Niño-3 SST for the horizontal velocity at the surface and at 100-m depth taken from the OGCM integration forced by the NCEP reanalysis. The composite differences suggest a strengthening (weakening) of the EUC, the SEC, and also the North Equatorial Countercurrent (NECC) during an anomalously warm (cold) eastern equatorial Pacific. From the cross-correlation function between the Niño-3 SST and indices for the strength of the zonal currents (averaged over the western tropical South Atlantic for the SEC, over the central tropical North Atlantic for the NECC, and over the central equatorial Atlantic for the EUC) a lag of 3 (6) months between the Niño-3 SST and the (sub)surface currents is found. These lags are similar to the lag between the Niño-3 SST and the southern TC index. The change in the zonal currents between El Niño and La Niña years is of the order of $5 \mathrm{~cm} \mathrm{~s}^{-1}$ or $10-15 \%$ of the mean velocity. The latter is about $40 \mathrm{~cm} \mathrm{~s}^{-1}$ in our OGCM simulation, which is somewhat weak compared to observations (e.g., Stramma and Schott 1999). The wind stress composite difference based on strong minus weak (threshold value 1 standard deviation) zonal current indices (not shown) suggests a change mainly in the southeasterly trades over the equatorial and tropical South Atlantic Ocean for the EUC and the SEC and a change in the trade winds over both the tropical North and South Atlantic Ocean for the NECC. 


\section{Discussion}

The results of our analysis suggest that El Niño influences the upper-ocean circulation in the tropical Atlantic Ocean by changing the Atlantic trade winds. To separate the effect of ENSO-induced trade wind and buoyancy flux changes, we have analyzed two sensitivity experiments with our NCEP-forced OGCM in which a climatological wind stress forcing or a climatological buoyancy forcing is prescribed, respectively. The Niño-3 composites for the upper-tropical Atlantic Ocean circulation from the climatological buoyancy flux experiment closely resemble the ones shown in Figs. 2a, 2d, and 2e. For the climatological wind stress experiment, however, nearly no changes in the upperocean circulation connected to changes in the Niño-3 SST can be found. The ENSO-induced wind stress pattern exhibits changes of the trade winds over the whole tropical Atlantic. Wind sensitivity experiments with our NCEP-forced OGCM in which climatological wind stress forcing was prescribed either within or poleward of the equatorial region show that most of the variability of the Southern Hemispheric TC, as well as the EUC and SEC, can be simulated with wind stress variability restricted only to the equatorial region.

Apart from the NCEP-forced OGCM integration, we have analyzed a 70-yr-long integration in which the OGCM was coupled to the atmosphere general circulation model ECHAM5 (Röckner et al. 1996). The response of the upper-ocean circulation in the tropical Atlantic to El Niño in the coupled model is quite similar to the one presented in this study. Therefore, our results seem not to be dependent on the type of surface forcing used. To investigate the sensitivity of the results to the particular ocean model used, we have analyzed a multicentury integration of the coupled general circulation model ECHAM4/Oberhuber Ocean Isopycnal Model (OPYC; Oberhuber 1993). Also in ECHAM4/ OPYC ENSO-induced changes in the upper-tropical Atlantic Ocean circulation can be found, although the response is much weaker than in the MPI-OM integrations. This might be due to the fact that the mean TC, as well as the mean zonal currents, is quite weak in this model integration (6 Sv for the Southern Hemispheric TC, $15 \mathrm{~cm} \mathrm{~s}^{-1}$ for the EUC as well as the NECC, and 30 $\mathrm{cm} \mathrm{s}^{-1}$ for the SEC).

To investigate, if any observational evidence for our model results can be found, we have analyzed sea surface height (SSH) data from both TOPEX/Poseidon and our NCEP-forced OGCM integration for the period 1993 to 2001. Figure 4 shows the composite based on warm observed Niño-3 SST (threshold value one standard deviation) for both the observed and simu- a)

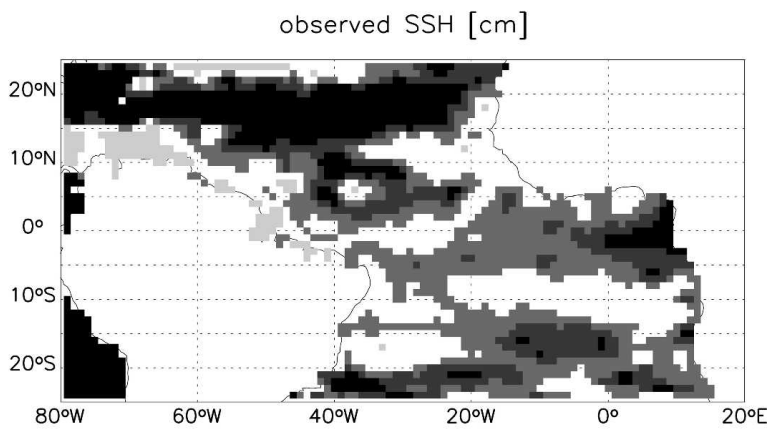

b)

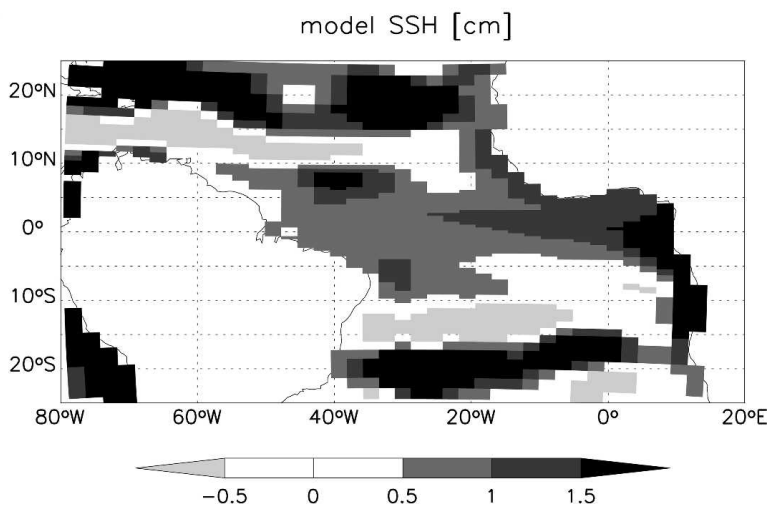

FIG. 4. Positive composite based on warm observed Niño-3 SST for the sea surface height (in $\mathrm{cm}$ ) from (a) TOPEX/Poseidon and (b) the OGCM integration forced by the NCEP reanalysis. The Niño-3 SST is leading by 4 months. All time series are monthly values with a 1-yr running mean applied and have been detrended prior to the composite analysis. The threshold value for the composite is 1 std dev of the Niño-3 SST index (1993-2001).

lated SSH. The positive composite represents basically the El Niño event $1997 / 98$. Between $10^{\circ} \mathrm{S}$ and $10^{\circ} \mathrm{N}$, where the main response to the Niño-3 SST of the upper Atlantic Ocean circulation is found, the simulated SSH is in good agreement (for both the pattern and the order of magnitude) with the observations. This gives us further confidence in our model results. Note that in Fig. 4 the Niño-3 SST is leading by 4 months (as for the composite difference for the shallow meridional overturning circulation), but a similar picture is obtained for a lag of 3 (6) months as for the composite difference for the zonal (sub)surface currents.

In Fig. 2f, the composite difference based on warm minus cold observed Niño-3 SST for the observed SST is shown. Anomalously warm (cold) Niño-3 SST is followed by a warming (cooling) of nearly the entire tropical Atlantic with the largest anomalies occurring in the northern tropical Atlantic (e.g., Enfield and Mayer 1997). Only in the eastern tropical South Atlantic is a weak cooling (warming) found. This is the region where the strongest cooling (warming) occurs during periods with a strong (weak) Southern Hemispheric TC. There- 
fore, it is likely that the ENSO-induced changes in the South Atlantic TC [warm (cold) Niño-3 SST leading to a strong (weak) TC] contribute to the SST anomalies in the eastern tropical South Atlantic found during periods with an anomalously warm (cold) Niño-3 SST. Considering the horizontal temperature advection (not shown) by the ENSO-induced horizontal surface current anomalies in the tropical Atlantic (and the mean observed horizontal temperature gradients), however, no influence on the SST during an anomalously warm (cold) Niño-3 SST can be seen. The ENSO-induced surface heat flux (not shown) contributes to the SST anomalies over most of the (sub)tropical Atlantic Ocean, but it has a damping effect over the eastern tropical South Atlantic. The contribution of the surface heat flux to the (simulated) SST anomalies, especially in the subtropical North Atlantic, can also be seen in the climatological wind stress experiment.

Acknowledgments. We thank Dr. Noel Keenlyside for helpful discussion during all stages of the work and Dr. Helmuth Haak and Dr. Peter Korn for their help with the ocean model integrations. The observed SST is provided by the Hadley Center. We thank three anonymous reviewers for their valuable comments on an earlier version of the manuscript. This work was supported by the Ocean-CLIVAR programme of the BMBF and the DYNAMITE project of the European Union.

\section{REFERENCES}

Chiang, J., Y. Kushnir, and S. Zebiak, 2000: Interdecadal changes in eastern Pacific ITCZ variability and its influence on the Atlantic ITCZ. Geophys. Res. Lett., 27, 3687-3690.

Curtis, S., and S. Hastenrath, 1995: Forcing of anomalous sea surface temperature evolution in the tropical Atlantic during Pacific warm events. J. Geophys. Res., 100, 15 835-15 847.

Enfield, D., and D. Mayer, 1997: Tropical Atlantic sea surface temperature variability and its relation to El Niño-Southern Oscillation. J. Geophys. Res., 102, 929-945.

Fratantoni, D., W. Johns, T. Townsend, and H. Hurlburt, 2000: Low-latitude circulation and mass transport pathways in a model of the tropical Atlantic Ocean. J. Phys. Oceanogr., 30, 1944-1966.

Hastenrath, S., and P. Lamb, 1977: Some aspects of circulation and climate over the eastern equatorial Atlantic. Mon. Wea. Rev., 105, 1019-1023.
Kalnay, E., and Coauthors, 1996: The NCEP/NCAR 40-Year Reanalysis Project. Bull. Amer. Meteor. Soc., 77, 437-471.

Keenlyside, N., and M. Latif, 2007: Understanding equatorial Atlantic interannual variability. J. Climate, 20, 131-142.

Latif, M., and T. Barnett, 1995: Interactions of the tropical oceans. J. Climate, 8, 952-964.

—, and A. Grötzner, 2000: The equatorial Atlantic oscillation and its response to ENSO. Climate Dyn., 16, 213-218.

Liu, Z., 1994: A simple model of the mass exchange between the subtropical and tropical ocean. J. Phys. Oceanogr., 24, 11531165.

_ 1998: The role of ocean in the response of tropical climatology to global warming: The west-east SST contrast. J. Climate, 11, 864-875.

Lu, P., J. McCreary, and B. Klinger, 1998: Meridional circulation cells and the source waters of the Pacific Equatorial Undercurrent. J. Phys. Oceanogr., 28, 62-84.

Marsland, S., H. Haak, J. Jungclaus, M. Latif, and F. Roeske, 2003: The Max-Planck-Institute global ocean/sea ice model with orthogonal curvilinear coordinates. Ocean Modell., 5, 91-127.

McCreary, J., and P. Lu, 1994: Interaction between the subtropical and equatorial ocean circulations: The subtropical cell. $J$. Phys. Oceanogr., 24, 466-497.

Moura, A., and J. Shukla, 1981: On the dynamics of droughts in northeast Brazil: Observations, theory and numerical experiments with a general circulation model. J. Atmos. Sci., 38, 2653-2675.

Oberhuber, J., 1993: Simulation of the Atlantic circulation with a coupled sea ice-mixed layer-isopycnal general circulation model. Part I: Model description. J. Phys. Oceanogr., 23, 808829.

Rayner, N., D. Parker, E. Horton, C. Folland, L. Alexander, D. Rowell, E. Kent, and A. Kaplan, 2003: Global analyses of SST, sea ice and night marine air temperature since the late nineteenth century. J. Geophys. Res., 108, 4407, doi:10.1029/ 2002JD002670.

Röckner, E., and Coauthors, 1996: The atmospheric general circulation model ECHAM-4: Model description and simulation of present-day climate. Max-Planck-Institut für Meteorologie Rep. 218, Hamburg, Germany, 90 pp.

Saravanan, R., and P. Chang, 2000: Interaction between tropical Atlantic variability and El Niño-Southern Oscillation. J. Climate, 13, 2177-2194.

Stramma, L., and F. Schott, 1999: The mean flow field of the tropical Atlantic Ocean. Deep-Sea Res. II, 46, 279-303.

Wu, L., Q. Zhang, and Z. Liu, 2002: Searching for the role of ENSO in tropical Atlantic variability using a coupled GCM. CLIVAR Exchanges, No. 7, International CLIVAR Project Office, Southampton, United Kingdom, 20-24.

Zhang, D., M. McPhaden, and W. Johns, 2003: Observational evidence for flow between the subtropical and tropical Atlantic: The Atlantic subtropical cells. J. Phys. Oceanogr., 33, 1783-1797. 